\title{
The Development of Student Worksheets in the Project Based Learning Model Oriented Project Assessment in the Thematic Learning in Fourth Grade of Elementary School
}

\author{
Fifi Astuti Alben Ambarita ${ }^{*} \quad$ Lilik Sabdaningtyas Darsono \\ Faculty of Teacher Training and Education, University of Lampung \\ St. S. Brojonegoro, No.1, Gedung Meneng, Bandar Lampung, Indonesia, 35145
}

\begin{abstract}
The purpose of this research and development is to produce student worksheets in the Project Based Learning model oriented project assessment that are suitable for use in learning, and to know the difference in learning outcomes between students using student worksheets in the Project Based Learning model oriented project assessment with do not use student worksheets in the Project Based Learning model oriented project assessment in thematic learning in fourth grade of elementary school. This type of research is research and development referring to the theory of Borg and Gall. The population of the study was 151 students of fourth grade of elementary school, and the sample was determined by purposive sampling as many as 20 students. The data was collected through observation sheets, questionnaires, and test questions. The test instrument that used fulfills the validity and reliability, taking into account the level of difficulty, and the power of the different questions. The data analysis technique used $t$ test. The results of the validation of the student worksheets in the Project Based Learning model oriented project assessment conducted by material experts, media experts, and linguists who were suitable to be used in learning. The results of the study showed that the student worksheets in the Project Based Learning model oriented project assessment of the project $t_{\text {count }}=2,838>t_{\text {table }}=1,697$. It means there are differences in learning outcomes between students who use student worksheets in the Project Based Learning model oriented project assessment with with do not use student worksheets in the Project Based Learning model oriented project assessment.
\end{abstract}

Keywords: the development of student worksheets, project based learning, project assessment

DOI: $10.7176 / \mathrm{JEP} / 10-17-10$

Publication date:June $30^{\text {th }} 2019$

\section{INTRDUCTION}

In the 21 st century human resources are needed that are able to work together, think high, creative, skilled, communication skills and lifelong learnin. Bialik \& Fadal (2015: 1) states that the skills that must be possessed by students in education in the 21 st century are Creativity, Critical Thinking, Communication, and Collaboration (4C). The skills of these students is suitable with the challenges that faced by students in the industrial era 4.0, in addition to the challenge that students have higher order thinking skills. Students must be able to critically assess all kinds of information obtained, and use it to solve problems or make the right decisions.Based on the results of observations on learning, interviews with teachers and students are obtained that: the teacher uses the students worksheet which only contains material and questions, the assessment on the students worksheet is in the form of tests, learning activities generally centered on the teacher delivering the material contained in the students' books limited, teachers have not given project assignments in learning and do not yet know how to evaluate them. Based on these facts, the steps taken to improve the development of the student worksheets in the Project Based Learning model oriented project assessment.

Prastowo (2011: 204) student worksheets are teaching materials that have been packaged in such a way that students are expected to learn teaching material independently. Student worksheets developed include material, learning instructions, summaries, and assignments related to the material, structured so that it is easy to understand the material made in the project. Majid (2014: 206) project assessment is an assessment of tasks that contain investigations and must be completed within a certain period / time. These tasks include planning, implementation, reporting. Project assessment is intended to find out the understanding of students applying their knowledge through the stage of investigation, the ability of students to provide information about something that is the result of their investigation. Student worksheets in the Project Based Learning model oriented project assessmentfocusing on project completion of real problems in the learning material.Pribadi (2009: 158) that students learn and build their knowledge, when they try to understand the environment around them. Students are brought in direct contact with the object or event that is being studied, thus providing the possibility to build a good understanding of the object or event.

The results of the needs analysis carried out on teachers in Public Elementary School in Pekalongan District on January 2018 showed that 100\% used teacher books and student books in learning, 85.71\% of teachers did not have supporting books that fulfilled the specified competencies, $71.43 \%$ teacher books and student books do 
not fulfill basic competencies, $100 \%$ of teachers have not given assignments to create projects and do not yet know how to assess students' projects, and $100 \%$ of teachers have not yet used the thematic worksheet.

Based on the description, it is necessary to do research and development of student worksheets in the Project Based Learning model oriented project assessment on thematic learning. The achievement of student learning success is inseparable from the ability or competence of the teacher to choose and determine the appropriate learning model and in accordance with the competencies to be achieved. One learning model that activates students is Project Based Learning. Abidin (2014: 169) Project Based Learning is a learning model that is oriented to develop the abilities and learning skills of students through a series of activities planning, carrying out research, and producing certain products framed in one container in the form of learning projects. Thomas in Sanjaya (2010: 144) Project Based Learning is a learning model that provides opportunities for teachers to manage classroom learning involving project work. Project Based Learning model is one of the learner-centered learning models, through research activities with teacher guidance and direction so that collaboration is established in accordance with their respective capacities comprehensively (Guo \& Yang, 2012).

Hosnan (2014: 325) Project Based Learning models are carried out by stages (a) project determination; (b) designing project completion steps; (c) preparation of project implementation schedules; (d) completion of projects with facilitation and monitoring of teachers; (e) preparation of report and presentation/publication of project results; (f) evaluation of project processes and results.Anita in Hosnan (2014: 329) the steps of Project Based Learning are carried out in 3 stages (1) Project planning phase, including formulating learning objectives, determining topics, grouping students with diverse ability levels consisting of 4-5 people, designing and compiling student worksheets, design learning resource needs, establish assessment plans. (2) Stage of project implementation, covering 6 activities, that are determining questions, arranging project plans, arranging schedules, monitoring, testing results and evaluating experiences. (3) The assessment phase includes the assessment of the planning, data collection, organizing, processing and presentation of the data. In addition to the selection of learning models, there are certainly many other factors to support the success of the students.Lestari (2013: 1) the ability of teachers to design or compile teaching materials becomes a very important role in determining the success of learning through a teaching material, such as student worksheets, as a medium or media for students to construct their knowledge in learning. Choo (2011: 519) student worksheets are instructional tools consisting of a series of questions and information designed to understand complex ideas, which guide students to carry out activities systematically.

Cakır in Töman (2013: 174) Worksheets are written materials consisting of individual activities which the students will do while learning a topic and also enable students to take responsibility for their own learning with the given process steps related to these activities.McDermott in Barniol (2016: 3) student worksheets provide learning experiences through inquiry and emphasis on building concepts. student worksheets have two main objectives, first is to guide the students in developing conceptual frameworks of important topics with difficult research for students, and the second is to overcome conceptual difficulties. Worksheets developed based on constructivist approaches enable students to actively participate during the learning process, help them to learn subject better, and increase student success noticeably (Toman, 2013: 178). The development of student worksheets which use the constructivism approach allows students to actively participate during learning. Student worksheets help students understand material better, and student worksheets can improve students' abilities.Darmodjo, et al. In Lestari (2013: 15) explain the requirements for the preparation of student worksheets (a) Didactic requirements that meet the principles of effective learning, that are: (1) Noting differences in individuals who have different abilities, not homogeneous; (2) Emphasize the process of finding a concept so that it serves as a guide for students to look for information rather than a means of notifying information;(3) Having a variety of stimulus through various media and student activities, providing opportunities for students to write, experiment, practice, and so on; (4) Developing social, emotional, moral, and aesthetic communication skills in students, (5) Determining learning experiences with students' personal development goals rather than subject matter. (b) Construction requirements include the use of language, sentence structure, vocabulary, level of difficulty, and clarity in the student worksheet.

(b) construction requirements, that are: (1) using language that matches the maturity level of students; (2) using a clear sentence structure; (3) have a sequence of lessons in accordance with the level of ability of students, meaning in simple things towards more complex things; (4) avoid questions that are too open; (5) refers to the standard book in the ability of students to be limited;(6) provide sufficient space to give students the breadth to write and describe the things students want to convey; (7) using simple and short sentences; (8) use more illustrations than words; (9) can be used for children both slow and fast; (10) has clear learning goals and benefits from it as a source of motivation and (11) has an identity to facilitate administration.(c) Technical Requirements, including (1) writing with regard to the use of printed letters and not using Latin / Roman letters, using rather large bold letters for the topics, using at least 10 words in 10 lines, using frames to distinguish command sentences from participants' answers students, using comparisons between letters and images in harmony. 
The success of students in learning requires an assessment of attitudes, knowledge, and skills. Assessment of attitude aspects is done through observation and appropriate assessment techniques, assessment of aspects of knowledge is done through written tests, oral tests, and assignments in accordance with the competencies assessed, while skills assessment is carried out through practice, products, projects, portfolios, and / or techniques others according to the competencies assessed.Student worksheets in the Project Based Learning model oriented project assessment is certainly expected to be relevant project assessment. Sean B. et al (2006: 2) learning outcomes is a process from the end of learning that has been done, seeing the success or failure of learning outcomes can be done by conducting an evaluation / test at the end of learning. Sunarti \& Rahmati (2014: 3) assessment is emphasized in authentic assessment.Authentic assessment is a comprehensive assessment to assess input, process, and learning outcomes. Basuki (2016: 168) authentic assessment is defined as a form of assessment that requires students to carry out real-world tasks that show the application of a knowledge or skill.

J. Micheal in (Callison 2015: 1) defines authentic assessment evaluation processes that involve multiple forms of reflecting performance measurement in the student's learning, achievement, motivation, and attitudes on instructionally-relevant activities. Authentic assessment assesses the learning process as a whole, not only on learning outcomes but also motivation and attitudes in each learning activity.J. Micheal (in Callison, 2015: 2) identifies the characteristics of authentic assessment (1) Constructed Response, assessment is able to measure students in constructing knowledge through various learning resources, (2) Higher-Order Thinking, assessment measures high-level thinking skills namely ability analyze, synthesize, and assess, (3) Authenticity, the task given must relate the material to the context of the real world or in everyday life, (4) Integrative; the assignment given can illustrate the integration of learning material. (5) Process and Product; assessment can measure learning processes and learning outcomes, and (6) Depth in Place of Breadth; performance builds various activities that enable active participants in learning.Aunthentic assessment, the teacher assesses the quality of the product or project that has been completed, not just testing knowledge with a written test. Project assessment is one type of authentic assessment. Djamarah (2000: 97) project assessment techniques will provide a comprehensive picture of the ability contextually regarding the ability of students to understand and apply concepts to certain materials.

Grossman (2007: 1-2), characteristics of project assessment (1) work in groups, students work together with their friends in a group. (2) centered on students, teachers facilitate learning. (3) multidisciplinary, requires reading, writing and research skills. (4) requires skills in the real world, for example using mathematical skills to analyze the project. (5) produce products, students work on a project or solve problems. (6) requires sufficient time to complete the project.Kusaeri (2014: 156) project assessment aims to a) obtain information about students' understanding and knowledge of learning, b) obtain information about the ability of students to apply knowledge and express their opinions, c) assess skills and knowledge that require applications, such as working in group, problem solving, and evaluation of findings.Amri \& Iif (2014: 94) explains that thematic learning is integrated learning that uses themes to link several subjects so that they can provide meaningful experiences to the students. Rusman (2015: 162) states that thematic learning has characteristics centered on learners, provides direct experience, subjects are not very clear, flexible, learning outcomes according to the interests and needs of students, and presents concepts from various subjects.

Based on this description, it is very urgent to carry out research and development with the aim of producing development of student worksheets in the Project Based Learning model oriented project assessment that are feasible, and to know the difference in learning outcomes between students using student worksheets in the Project Based Learning model oriented project assessment with with do not use student worksheets in the Project Based Learning model oriented project assessment on thematic learning in fourth grade of Elementary School.

\section{RESEARCH METHODS}

The type of research using research and development refers to the theory of Borg \& Gall (1983: 772) on Reasearch-Based-Development according to the purpose of research, namely research procedures with the aim of developing and validating educational products developed. Borg and Gall (2003: 569-575) research and development procedures, namely research and information collecting, planning, developing preliminary form of product, preliminary field testing, main product revision, playing field testing, operational product revision, operational field testing, final product revision, and dissemination and implementation. The research and development carried out only reached the seventh step, because of the limitations of researchers, both in terms of time and cost.

The study population was fourth grade students of the State Elementary School Pekalongan District who had implemented the 2013 curriculum, namely SDN 1 Adirejo, SDN 1 Gantiwarno, SDN 1 Gondangrejo, SDN 1 Pekalongan, and SDN 1 Sidodadi with 151 people. The sample was determined using purposive sampling with the consideration that SDN 1 Gondangrejo.as as a school the 2013 curriculum implementation model numbered 20 students. 
The development of worksheets data collection tool for the project-oriented PjBL model uses a questionnaire, namely material, media, and language validation. The material aspects of the worksheets include suitability for project-oriented assessment, and quality of content. The aspects of the worksheets media fulfill didactic, construction, and technical requirements. Language aspects fulfill the writing requirements. The stages of project evaluation used refer to steps by Purnomo (2016: 55) in the planning, data collection, data processing, and data presentation stages.

Learning outcomes obtained from the results of the pretest and posttest of learning using the worksheets model PjBL-oriented project, using valid and reliable test instruments, and considering the level of difficulty and the power of different questions. Multiple choice instruments are given a score of 1 for correct answers and a score of 0 for wrong answers. The results of learning skills using the observation sheet. Data analysis techniques to see the difference between the use of the project-oriented PJBL model worksheets with students with do not use student worksheets in the Project Based Learning model oriented project assessment using the $t$ test. The $t$ test is used to find out whether there is a difference between the two means of the two sample / group / data categories. The $t$ test that will be used in this study is the paired t-test to determine the effectiveness of the project-oriented worksheets. According to Sugiyono (2015: 417) testing the significance of effectiveness and data in the form of intervals and carried out in two groups, it can use paired t-tests.

\section{RESEARCH RESULTS AND DISCUSSION}

\subsection{Results The Development Of Student Worksheets In The Project Based Learning Model Oriented Project} Assessment In The Thematic Learning In Fourth Grade Of Elementary School

The results of research and development of student worksheets in the Project Based Learning model oriented project assessment on thematic learning in fourth grade students in Public Elementary School 1 Gondangrejo, product development with the development procedure refers to the development model Borg \& Gall (2003: 569575) obtained the following results.

\subsubsection{Information and Research Collecting (Research and Information)}

Field studies are carried out using observation sheets relating to the description of learning conditions including student learning motivation, availability of teaching materials, infrastructure, and student learning outcomes and needs analysis. While the literature study is conducted by examining theories related to research topics, from books and sources that are relevant to the research conducted. Observation results of analysis of student learning outcomes are obtained (1) Learning ability of students is still low, (2) teachers still dominate the implementation of learning, (3) teaching materials used do not meet the needs of students and curriculum demands, (4) students are not challenged to connect their knowledge into learning material so that less motivated students explore their own knowledge, (5) learning must be conducted actively, inspirational, fun and challenging, (6) the student worksheets that made must be able to facilitate students to think critically, creative and independent, (7) there are still students whose values are below the Minimum Completion Criteria, and (8) the assessment carried out has not referred to the specified assessment standards.

Analysis of teacher needs obtained the following data: (1) Student learning outcomes are still many under the Minimum Completeness Criterion, (2) student worksheets used from publishers are less helpful for students to understand the material, (3) require teaching materials student worksheets that fulfill the curriculum and needs of students and increase their participation and learning outcomes. The results of the teacher's needs analysis show that it is necessary to make student worksheets in the Project Based Learning model oriented project assessment.

\subsubsection{Planning}

Student worksheets in the Project Based Learning model oriented project assessment in thematic learning in fourth grade of Elementary School includes: a) making instructional analysis that are loading competency maps, developing indicators, and setting learning objectives; b) collection of materials that are in accordance with the material, obtained and developed from relevant book sources; c) make draft of the student worksheets in the Project Based Learning model oriented project assessment, d) the process of making student worksheets, paying attention to the structure and systematics of student worksheets including titles, learning instructions, supporting information, assignments, and steps learning. e) planning evaluation tools, including material analysis and assessment.

Evaluation tools used in student worksheets include assignments and questions in the form of multiple choice tests. The design of the assessment instrument was prepared based on the theoretical study that had been put forward and in the form of a questionnaire with a Likert scale. The questionnaire consists of 4 answer choices that are $1,2,3$, and 4 , each of which states that it is not good, good enough, good and very good that is used to assess the quality of attractiveness of student worksheets that developed and the suitability of student worksheets. There are three components of conformity in this questionnaire, that are: the appropriateness of the contents of the students worksheet, the suitability of the student worksheets in the Project Based Learning model oriented project assessment and the suitability of student worksheets with the requirements for making student 
worksheets.

\subsubsection{Develop Preliminary Form of Product}

The initial product development steps are (1) Determine the elements of the student worksheet consisting of (i) headline / page, (ii) introduction (iii) table of contents, (iv) instructions for using the students worksheet, (v) mapping of Basic Competence (vi) learning activities in accordance with the student worksheets in the Project Based Learning model oriented project assessment, and (vii) competency test. (2) Collecting material that is in accordance with predetermined material (i) designing the display of student worksheets and (ii) producing student worksheets oriented to the projectassessment. (3) Development of the Initial Product Format, carried out part by part in accordance with the framework of the students worksheet which have been compiled.

The drafting of the student worksheets in the Project Based Learning model oriented project assessment is the cover (title page) encompassing (i) Title is determined based on the design stage, (ii) Name of the student worksheet is Fifi Astuti, (iii) Identity of student worksheets for administrative needs, (iv) Figure supporting the front cover section is to briefly describe the contents of the developed student worksheet, (v) The target of the student worksheet that developed, (vi) Description of the student worksheet is the intention of making and the use of product worksheets from the results of research research, (vii) Background color of student worksheets, and other completeness.

\subsubsection{Preliminary Field Testing}

Conducted two activities, namely product validation test by experts and limited trials of students. Product validation tests are carried out by media experts, material experts, and linguists with the aim that the products produced in the form of worksheets can be used by students. This internal test consists of the test of material experts, media experts, and linguists. The expert expert review of the development of teaching materials for worksheets in the Project Based Learning model oriented project assessment, providing advice on 1) so that all teaching material is projected 2) equipped with time allocation 3) equipped with moral instruction 4) for report format. The score obtained in the first assessment by the material validator is 78.33 , and the results of the expert test results of the material after guiding as many as 2 (two) meetings are 92.5. Expert testing on the development of teaching materials for project-oriented $\mathrm{PjBL}$ models provides a correction of the interrelationship between the sub themes of the central theme of natural diversity of science, ends with a message of moral diversity. Judging from the design of the worksheets with the terms of making worksheets which consists of three aspects of assessment, namely didactic, construction and technical requirements. The results of data analysis results from the validation of media experts, the developed worksheets obtained a score of 82 valid and was worth implementing. Linguist validation provides advice on readability, so that the sentence meets the criteria for effective sentences, as a whole worksheets products are feasible (valid) so that the worksheets can be used and implemented, with a score of 88.46. Validation by the Teacher shows that the worksheets in the Project Based Learning model oriented project assessment, feasible for use in learning, with little improvement. The results of product validation were continued by small group trials of 9 students (each of 3 people representing high-ability, moderate-ability, and low-ability)

\subsubsection{Main Product Revision}

shows that there is a significant increase in learning outcomes, so that the product does not need to be revised, and is feasible to be tested in large groups.

\subsubsection{Main Field Testing}

conducted after revision according to expert and practitioner suggestions and stated that worksheets products are suitable for use in learning. The trial was carried out with the control group IVA class students while the experimental group IVB class students. The results of the main field trials, did not find anything that needed to be revised from the product and feasible to be tested on the operational field test.

\subsubsection{Operational Product Revision}

carried out after the main field trial to perfect the product, taking into account comments and suggestions during the previous testing.

3.2 The differences in learning outcomes between students who use student worksheets in the Project Based Learning model oriented project assessment with do not use student worksheets in the Project Based Learning model oriented project assessment.

The effectiveness of student worksheets is done through a test of differences in learning outcomes with an independent $t$ test. The calculation results are obtained as in the following table.

Table 1. Independent t test results

\begin{tabular}{|c|c|c|c|c|c|}
\hline $\mathbf{n}_{\mathbf{1}}$ & $\mathbf{n}_{\mathbf{2}}$ & $\overline{x_{1}}$ & $\overline{x_{2}}$ & $\mathbf{t}_{\text {count }}$ & $\mathbf{t}_{\text {table }}$ \\
\hline 20 & 20 & 78,60 & 70,00 & 2,838 & 1,697 \\
\hline
\end{tabular}

Test criteria:

a) If $t_{\text {coun }} t>t_{\text {table }}$ then $\mathrm{H} 1$ is accepted and $\mathrm{H} 0$ is rejected 
b) If $t_{\text {count }}<t_{\text {table }}$ then $\mathrm{H} 0$ is accepted and $\mathrm{H} 1$ is rejected

Based on the results of the $t$-test in the table, it is known that the results of the $t_{\text {count }}=2,838$ while $t_{(\alpha=0.5)}=1,697$, it turns out $\mathrm{t}_{\text {count }}=2,838>\mathrm{t}_{\text {table }}=1,697$ then $\mathrm{H} 1$ is accepted and $\mathrm{H} 0$ is rejected. That is, there are differences in learning outcomes between students who use student worksheets in the Project Based Learning model oriented project assessment with do not use student worksheets in the Project Based Learning model oriented project assessment.

\subsection{Discussion}

\subsubsection{The development of student worksheets in the Project Based Learning model oriented project assessment} that feasible in thematic learning in fourth grade of Elementary School

Research and development of thematic student worksheets through Project Based Learning model oriented project assessment in thematic learning, adapting nine steps of R \& D by Borg \& Gall (2003: 569-575), the first stage is research and initial information gathering, understanding problems, planning research on developing teaching materials for student worksheets that can improve learning outcomes. Next, compile the initial product sheet of student worksheets, by pouring research into the development of student worksheets in the Project Based Learning model oriented project assessment. The next stage of the initial pilot research was to test material, media, and language validation by three validators, with the aim of validating the product being developed, in order to fulfill the research requirements and be worthy of testing. The results of the material validation test include the suitability of the student worksheet with the project-based curriculum and Project Based Learning model oriented project assessment.

Media validation includes the requirements for making student worksheets, that are didactic, construction, and technical requirements. Language validation includes sentence structure, readability, effective sentence criteria. Practitioner's validation includes the suitability of the content, and the requirements for making student worksheets. After several consultations and repairs, the product is feasible to be implemented. The main field testing phase, conducted the effectiveness test of the student worksheet first, followed by testing the experimental group products, obtained the data on student learning outcomes increased from the pretest results on the posttest results.

The next stage, revision for product improvement. The control group test results showed an increase in learning outcomes from the pretest to the posttest. The learning carried out by the implementation of the student worksheets in the Project Based Learning model oriented project assessment, according to Semiawan (2006:84) with orientation stages, planning, implementation and evaluation. Sukardjo (2012: 54) learning emphasizes that individuals gain knowledge from the process of forming knowledge by connecting knowledge that has been previously possessed with current knowledge. The student worksheets in the Project Based Learning model oriented project assessment, can be applied well because it involves students directly and systematically.

Suhana (2012: 77) Project Based Learning model oriented project assessment is a series of learning activities that involve a maximum of all components of students to find and investigate systematically, critically and logically to find their own knowledge, attitudes and skills as a manifestation of change. Students are active in the learning process, making learning more active and innovative, finding and solving problems themselves, and can link knowledge and experience with everyday life, easily absorb information and process new material, which has an impact on improving learning outcomes.

Podolak Ken and Jordyn Danforth (2013) show that the use of student worksheets is able to provide experience to students, making students learn more actively, and overcome learning difficulties of students. Ozmen \& Yildirim (2011) and Lee (2014) show that student worksheets effectively support student book supplements. Teaching materials developed by student worksheets can be used as alternative teaching materials in the learning process in the classroom and as an independent learning material for students.

3.3.2 Differences in learning outcomes between students using worksheets in the Project Based Learning model oriented project assessment with students who do not use project-oriented worksheets

The effectiveness of worksheets in the Project Based Learning model oriented project assessment was seen from the differences in the results of the pretest and posttest learning between the experimental class and the control class. The results of the analysis using the $t$ test show that the learning outcomes of students using the worksheets PjBL model oriented to the project is higher than the learning outcomes do not use project-oriented worksheets. Yoranda et al. (2013: 35) showed that the use of the project-oriented PjBL model worksheets differs significantly from the posttest learning outcomes in the experimental class, compared to those using publisher worksheet. This is in accordance with the opinion of Slameto (2003: 2), that someone who learns will get a change in behavior, attitudes and actions on him. Mondolang (2013) shows that project appraisal techniques are able to help students apply their knowledge in solving problems. These behavioral changes will be accompanied by effort and hard work. Wiyarsi\& Erfan (2011) show that there are significant differences in student achievement in participating in learning by applying project-based assessment with students who take part in learning without the application of project-based assessment. That is, the quality of learning is related to the 
learning process which has an impact on improving learning outcomes. Barniol (2016) showed that learning using worksheets in tutorials proved to be significantly effective in improving student learning outcomes. Learning is a change in a person's behavior based on his experience in interacting with his environment. In the learning process, learning outcomes, ways of learning, and learning strategies will influence the development of one's thinking and schema. In an effort to gain understanding or knowledge, students use their experience, cognitive structure, and beliefs. Bielefeldt \& Underwood in Ngalimun (2013: 197) states that a) increasing student motivation, b) learning in the project is more fun than other curriculum components, c) improving problem solving skills, d) increasing collaboration, e) improving skills in managing resources and f) provide experience to students learning and practice in organizing projects, and making time allocations and other resources such as equipment to complete tasks.

The use of worksheets teaching materials developed effectively improves learning outcomes. This happened, because the worksheets material was developed in accordance with content standards, and the process standards applied the project assesment oriented PjBL model. Group discussion and collaboration can be carried out well, and learning is carried out according to the syntax of PjBL by Semiawan (2007: 84), namely the planning, implementation, and assessment stages. Ozmen and Yildirim (2011: 52) show that the use of activity sheets by fulfilling procedures can improve student learning achievement. The results of the study show that the worksheets in the Project Based Learning model oriented project assessment is effective in improving learning outcomes. Sariwati M Shariff, Zaimy Johana Johan \& Norina Ahmad Jamil (2013) shows that the provision of group projects is one form of learning process for students to explore, learn by doing and organizing concrete activities. This is seen from the average value of students using worksheets in the Project Based Learning model oriented project assessment which is 80.05 higher compared to the average value of students who do not use the worksheets in the Project Based Learning model oriented project assessment which is 70.00. This can happen, because learning uses the project-oriented $\mathrm{PjBL}$ model worksheets, students are required to systematically follow each stage. The moral of this research is in accordance with the study of Sariwati M Shariff, Zaimy Johana Johan, \& Norina Ahmad Jamil (2013) showing that group projects is a form of learning process for students to explore, learn by doing and organizing tangible activities.

\subsubsection{Limitations on the development of Worksheets In The Project Based Learning Model Oriented Project Assessment}

Some limitations on worksheets products from this study are: (1) worksheets teaching materials only provide one sub-theme, (2) effectiveness testing of of Worksheets in the project based learning model oriented project assessment conducted in one school, (3) potential and problems focused only on class IV and the difficulties faced are still around the national curriculum, (4) the development of the product is limited by reference to the teacher's books and student books, (5) expert validators only one expert for each material, media, and language, (6) small group trials are still found students who are confused, thus inhibiting implementation is not optimal, (7) revisions from practitioners are carried out by one teacher and learners from one school, and (8) field trials are conducted in two classes, so researchers cannot directly observe learning.

\subsubsection{Limitations of the Research}

(1) the research instrument was tested only once, (2) using one school as a place of research, (3) the development of teaching materials is only limited to one sub-theme, so that it is considered less comprehensive in meeting the needs of students.

\section{CONCLUSION}

Based on the results of research and development of Student Worksheets in the Project Based Learning model oriented project assessment can be concluded that: (1) after the revision refers to validator suggestions and corrections, the worksheet products developed by students are worthy of use in learning, with a score of 92.5 material, score 82.0 from media experts, and score 88.46 from experts. (2) Learning outcomes of students who use developed student worksheets are significantly higher compared to students who use the students worksheet that made by publishers.Learning that uses student worksheets in the Project Based Learning model oriented project assessment can improve student learning outcomes, have complex learning experiences, are designed according to the real world, making it easier for students to understand and remember the material.

\section{SUGGESTION}

Worksheets in the project based learning model oriented project assessment requires creative educators to present material and project appraisal, have the ability and skills, engage students actively according to low, medium, and high absorptive capacity.

\section{REFERENCES}

Abidin, Yunus. 2014. Desain Sistem Pembelajaran dalam Konteks Kurikulum 2013. PT Refika Aditama. Bandung. 
Amri, Sofan dan Iif Khoiru Ahmadi. 2014. Pengembangan dan Model Pembelajaran Tematik Integratif. Prestasi Pustaka. Jakarta.

Barniol, Pablo. 2016. A Tutorial Worksheet to Help Students Develop the Ability to Interpret the Dot Product as a Projection. Eurasia Journal of Mathematics, Science \& Technology Education.

Basuki, I. \& Hariyanto. 2016. Asesmen Pembelajaran. Remaja Rosdakarya. Bandung.

Bialik, M \& Fadel, C. 2015. Skill for the 21st Century. Center for Curriculum Redesign. Boston.

Borg \& Gall. 1983. Educational Research: An Introduction (4 th ed). Longman Inc. New York \& London.

Borg, W.R dan Gall, M.D. 2003. Educational Research an Introduction. Longman Inc. New York.

Callison, Daniel. 1998. Authentic Assessment. School of Library and Information Science, and Director, Library Science and Scholl Media Education, Indiana University, Bloomington. Scholl Library Media Activities Monthly 14, No. 5.

Celikler, Dilek. 2010. The Effect of Worksheet Developed for the Subject of Chemical Compounds on Student Achivement and Permanent Learning. Educational Research Asspciation. The International Journal of Researchin Teacher Education. Volume 1 No. 1 Hal. 42-51.

Choo, Serene S. Y. 2011. Effect of Worksheet Scaffolds on Student Learning in Problem-Based Learning. Journal of Health Science Education, Vol. 16. No. 5.

Djamarah, Syaiful Bahri. 2000. Guru dan Siswa dalam Interaksi Edukatif. Rineka Cipta. Jakarta.

Gültekin, Mehmet. 2005. The Effect of Project Based Learning on Learning Outcomes in the 5 Grade Social Studies Course in Primary Education. Educational Sciences: Theory \& Practice. Volume 5 No. 2. Hal 548556.

Guo,Shaoqing and Yang,Yanjun.2012.Project-Based Learning: An Effective Approach to Link Teacher Professional Development and Students Learning. Journal of Educational Technology Development andExchange (JETDE): Vol. 5: Iss. 2 , Article 5.

Harms, U., Krombab, A. 2008. Acquiring knowledge about biodiversity in museum-ar worksheet effective. Journal of Biological Education (Society of Biology), 42(4), 157-163. Retrieved from http://www.societyofbiology.org/aboutus

Hosnan, M. 2014. Pendekatan Saintifik dan Kontekstual Dalam Pembelajaran Abad 21. Ghalia Indonesia. Bogor.

Kunandar. 2013. Penilaian Authentik (Penilaian Hasil Belajar Peserta Didik Berdasarkan Kurikulum 2013). Rajawali Pers. Jakarta.

Kusaeri. 2014. Acuan dan Teknik Penilaian Proses dan Hasil Belajar dalam Kurikulum 2013. Ar-Ruzz Media. Yogyakarta.

Lee, Che Di. 2014. Worksheet Usage, Reading Achievement, Classes' Lack of Readiness, and Science Achievement: A Cross-Country Comparison. International Journal of Education in Mathematics, Science and Technology. Volume 2. Hal 97-105.

Lestari, Ika. 2013. Pengembangan Bahan Ajar Berbasis Kompetensi. Akademia Permata. Padang.

Majid, Abdul. 2014. Penilaian Autentik Proses dan Hasil Belajar. Rosda. Bandung.

Mondolang. A. H. 2013. International Institute for Science, Technology and Education. Journal of Education and Practice. Vol. 4.

Ngalimun. 2013. Strategi dan Model Pembelajaran. Aswaja Pressindo. Yogyakarta.

Ozmen \& Yildrim. 2011. Effect of Worksheets on Student's Succes: Acid and Based Sample. Journal of Turkish Education. Volume 2 Issue 2.

Podolak Ken \& Jordyn Danforth. 2013. Interactive Modern Physics Worksheets Methodology and Assessment. European J of Physics Education. Vol.4

Prastowo, Andi. 2011. Panduan Kreatif Membuat Bahan Ajar Inovatif. Diva Press.Yogyakarta.

Pribadi, Benny A. 2009. Model Desain Sistem Pembelajaran. Dian Rakyat. Jakarta.

Purnomo, Edi. 2016. Dasar-Dasar dan Perancangan Evaluasi Pembelajaran. Media Akademi. Yogyakarta.

Rohaeti, Eli. Widjajanti, E. Padmaningrum Tutik Regina. 2008. Kualitas Lembar Kerja Siswa. Universitas Negeri Yogyakarta. Jurnal Inovasi Pendidikan, vol 10. No 1.

Rusman. 2015. Pembelajaran Tematik Terpadu. PT.Raja Grafindo Persada. Jakarta.

Sanjaya, Wina. 2007. Strategi Pembelajaran Berorientasi Standar Proses Pendidikan. Prenada Media Group. Jakarta

Sean B. Eom and H. Joseph Wen, Nicholas Ashill. 2006. The Determinants of Students' Perceived Learning Outcomes and Satisfaction in University Online Education : An Empirical Investigation. Decision Sciences Journalof Innovative Education, Printed in the U.S.A. Volume 4. No. 2.

Semiawan, Conny R. 2007. Catatan Kecil tentang Penelitian dan Pengembangan Ilmu Pengetahuan. Kencana Prenada Media Grup.Jakarta

Shariff, Sariwati M, Zaimy Johana Johan, Norina Ahmad Jamil. 2013. Assessment of Project Management Skills and Learning Outcomes in Students' Projects. Procedia - Social and Behavioral Sciences. Vol. 90 Hal. $745-754$. 
Slameto. 2010. Belajar dan Faktor-Faktor yang Mempengaruhinya. Rineka Cipta. Jakarta.

Sugiyono. 2015. Metode Penelitian dan Pengembangan. Alfabeta. Bandung.

Sukardi. 2008. Evaluasi Pendidikan. Bumi Aksara. Jakarta.

Sunarti dan Rahmawati, Selly. 2014. Penilaian dalam Kurikulum 2013. Andi. Yogyakarta

Suprihatiningrum, Jamil. 2013. Strategi Pembelajaran Teori \& Aplikasi. Ar-Ruzz Media. Yogyakarta.

Töman, Ufuk., Riza, Akdeniz Ali., and Odabaşi Cimer Sabiha. 2013. Extended Worksheet Developed According To 5e Model Based On Constructivist Learning Approach. International Journal on New Trends in Education andTheir Implications. Vol. 4 (4): 173-183.

Yildirim, Nagihan, et al. 2011. The Effect of the Worksheets on Students'Achievement in Chemical Equilibrium. Journal of Turkish ScienceEducation, 8(3), 44-58.

Widjajanti, Endang. 2008. Kualitas Lembar Kerja Siswa Mata Pelajaran Kimia. UNY: Yogyakarta.

Wiyarsi, Antuni dan Priyambodo, Erfan. 2011.Efektivitas Pnerapan Penilaian Proyek (Project Based Assessment) pada Pembelajaran Kimia terhadap Kemampuan Berpikir Kritis dan Ketuntasan Belajar Kimia SMA Sleman. Prosiding Seminar Nasional Kimia Unesa. ISBN:978-979-028-378-7 